\title{
STUDI KOMPARASI JUMLAH MIKROORGANISME PADA BUS AC DAN NON AC EKONOMI JURUSAN PURWOKERTO-YOGYAKARTA TAHUN 2015
}

\author{
Shinta Dewi Jayanti ${ }^{1)}$, Nur Hilal ${ }^{2)}$ \\ Jurusan Kesehatan Lingkungan, Politeknik Kesehatan Kemenkes Semarang, \\ Jl. Raya Baturaden KM 12 Purwokerto, Indonesia
}

\begin{abstract}
Abstrak
Bus merupakan angkutan umum yang digunakan oleh masyarakat pada umumnya untuk memperlancar mobilitas dari satu kota ke kota yang lain. Untuk kenyamanan penumpang selama perjalanan, digunakan Air Conditioner (AC) sebagai penyejuk dan penghawaan ruangan. Salah satu media yang berperan dalam penularan dan penyebaran penyakit adalah udara. Penelitian dilaksanakan untuk mengetahui jumlah mikroorganisme udara pada bus AC dan non AC, kondisi kebersihan ruangan. Metode penelitian yang digunakan adalah penelitian observasional dengan pendekatan Crosssectional. Pengambilan sampel menggunakan metode purposive sampling sebanyak 8 sampel. Hasil penelitian jumlah mikroorganisme udara tertinggi pada bus AC adalah 4.790.000 $\mathrm{CFU} / \mathrm{m}^{3}$, sedangkan terendah adalah $2.750 \mathrm{CFU} / \mathrm{m}^{3}$, Untuk bus non AC tertinggi $57.500 \mathrm{CFU} / \mathrm{m}^{3}$, dan terendah $30.000 \mathrm{CFU} / \mathrm{m}^{3}$. Analisis menggunakan uji t- test didapat 0,044. Berdasarkan hasil penelitian disimpulkan bahwa ada perbedaan yang signifikan jumlah mikroorganisme udara pada bus AC dan non AC ekonomi jurusan Purwokerto - Yogyakarta. Untuk mengurangi jumlah mikroorganisme udara sesuai dengan hasil yang diperoleh, maka perlu dilakukan pembersihan dan pencucian bus secararutin minimal setelah bus beroperasi. Pengecekan sarana yang dapat mengganggu kesehatan dan keselamatan penumpang, termasuk pengecekan AC secara berkala pada bus. Sebaiknya penumpang tidak merokok dan tetap menjaga kebersihan selama perjalanan.
\end{abstract}

Kata kunci : mikroorganisme, bus ekonomi

\section{Abstract}

The Microorganism Number Comparison Study Between Air-conditioned and Non-Air ConditionedEconomic Class Purwokerto - Jogja Operation area Year of 2015. Bus is public transport used by public to support mobility from one city to another. For passenger comfort during travel, the Air Conditioner (AC) was used as conditioning and room's air circulation. The media that also hada role in the disease's transmission and was air. The research was conducted to determine the number of microorganisms in the air conditioned buses and non-air conditioning, room sanitation conditions. The method used was observational research with cross sectional approach. The sampling method used was purposive sampling method, obtained 8 samples. The research result shows that the highest microorganisms number on air conditioned bus was 4.79 million $\mathrm{CFU} / \mathrm{m}^{3}$, while the lowest was 2,750 CFU / $\mathrm{m}^{3}$, whereas for non AC bus, the highest value was 57,500 $\mathrm{CFU} / \mathrm{m}^{3}$, and the lowest was 30,000 CFU / $\mathrm{m}^{3}$. The t-test analysis obtainedp-value $=0,044$. Based on this results it can be concluded that there were significant differences of microorganisms number in air conditioned and non-air conditioned economics buses of Purwokerto- Yogyakarta operation area. To reduce the amount of air microorganisms, it is necessary to conducting cleaning and washing bus regularly at least after the bus operation. Checking tools that can interfere the passengers health and safety, including checking AC periodically. We recommend that passengers do not smoke and maintain hygiene during traveling.

Keywords : microorganisms, economic bus

\section{PENDAHULUAN}

Udara merupakan salah satu komponen lingkungan yang paling utama untuk mempertahankan kehidupan. Apabila kualitas udara buruk maka kesehatan juga akan terganggu. Salah satu upaya yang dilakukan ialah penyehatan udara. Penularan penyakit melalui udara dapat terjadi karena kondisi lingkungan yang buruk, baik di lingkungan pemukiman, tempat-tempat umum, transportasi atau kendaraan umum.
Kendaraan umum merupakan fasilitas yang perlu diawasi kualitas kesehatannya, salah satunya yaitu kualitas udara. Gangguan kesehatan manusia yang ditimbulkan akibat buruknya kualitas udara ialah infeksi saluran pernafasan, TBC, Diphteri. yang dilakukan oleh Justisia Ayu Syailendra pada tahun 2005 yang mengukur tentang jumlah mikroorganisme di dalam Bus didapatkan 70 koloni / $\mathrm{m}^{3}$ pada Bus AC dan 60 koloni / $\mathrm{m}^{3}$ pada Bus Non AC. Sedangkan penelitian yang dilakukan oleh Nurulita Budi Susanti

1) Email : -

2) Email : Inung.nh@gmail.com 
pada tahun 2008 di dalam Bus didapatkan hasil 2813 koloni / cm² pada Bus AC dan 6797 koloni/ $\mathrm{cm}^{2}$ pada Bus Non AC. Tujuan dari penelitian ini adalah untuk mengetahui perbedaan jumlah mikroorganisme pada bus AC dan non AC ekonomi jurusan PurwokertoYogykarta.

\section{METODE}

Jenis penelitian ini adalah observasional dengan pendekatan crosssectional. Pengukuran dilakukan di dalam bus yang sedang beroperasi. Hasil pengukuran dianalisis menggunakan uji t-test.

\section{III.HASIL DAN PEMBAHASAN}

\section{Hasil}

Pengambilan sampel jumlah mikroorganisme udara dilaksanakan pada 4 bus AC dan 4 bus non AC Ekonomi. Bus tersebut kemudian diberi kode AC 1,2,3,4 dan non AC 1,2,3,4. Berdasarkan hasil pemeriksaan jumlah mikoorganisme di laboratoium didapatkan hasil sebagai berikut : AC1=4.790.000 $\mathrm{CFU} / \mathrm{m}^{3}$, AC $2=1.425 .000 \mathrm{CFU} / \mathrm{m}^{3}, \quad \mathrm{AC} 3=2.750$ $\mathrm{CFU} / \mathrm{m}^{3} \mathrm{AC}, \mathrm{AC} 4=41.500 \mathrm{CFU} / \mathrm{m}^{3}$. Sedangkan hasil pada bus non AC adalah sebagai berikut non AC 1 $=30.000 \mathrm{CFU} / \mathrm{m}^{3}$, nonAC $2=57.500 \mathrm{CFU} / \mathrm{m}^{3}$, non AC $3=25.250 \mathrm{CFU} / \mathrm{m}^{3}$, non AC $4=30.500 \mathrm{CFU} / \mathrm{m}^{3}$. Rata-rata Kondisi sanitasi pada bus AC adalah 67\% dan pada bus non AC adalah 51\%.

\section{Pembahasan}

Jumlah mikroorganisme terbanyak pada sampel bus AC adalah 4.790.000 $\mathrm{CFU} / \mathrm{m}^{3}$. Pengambilan sampel udara di dalam ruangan bus AC tersebut, dilakukan pada hari pertama pada pukul 10.00 WIB yang terdapat 24 penumpang dengan suhu ruangan $27^{\circ} \mathrm{C}$, kelembaban $64 \%$ dan kecepatan udara $1,3 \mathrm{~m} / \mathrm{s}$. Banyaknya mikroorganisme dalam ruangan bus AC tersebut dipengaruhi oleh laju ventilasi, padatnya orang, dan kegiatan orang-orang yang menempati ruangan tersebut. Kondisi kebersihan bus yang cukup dan perawatan AC yang hanya dilakukan 6 bulan serta tidak adanya laju ventilasi membuat jumlah mikroorganisme dalam ruangan bus AC tersebut sangat tinggi.

Berdasarkan hasil pemeriksaan kondisi kebersihan ruangan pada bus AC didapatkan hasil rata - rata $67 \%$ dan kondisi kebersihan ruangan pada bus non AC didapatkan hasil rata - rata 51\%. Menurut Suharsini Arikunto (1991) kondisi kebersihan ruangan bus AC adalah cukup dan kebersihan ruangan pada bus non AC adalah kurang baik.

\section{IV.SIMPULAN DAN SARAN}

\section{Simpulan}

Jumlah mikroorganisme udara pada bus AC Jurusan Purwokerto-Yogyakarta yang tertinggi adalah 4.790.000 CFU/ $\mathrm{m}^{3}$ dan terendah adalah 2.750
$\mathrm{CFU} / \mathrm{m}^{3}$. Jumlah keseluruhan mikroorganisme adalah 6.259.250 $\mathrm{CFU} / \mathrm{m}^{3}$, dan rata-ratanya adalah 1.564.812,5 CFU/m $\mathrm{m}^{3}$. Jumlah mikroorganisme udara pada bus non AC Jurusan Purwokerto-Yogyakarta yang tertinggi adalah $57.500 \mathrm{CFU} / \mathrm{m}^{3}$ dan terendah adalah $25.250 \mathrm{CFU} / \mathrm{m}^{3}$. Jumlah keseluruhan microorganism adalah $143.250 \mathrm{CFU} / \mathrm{m}^{3}$, dan nilai rata-ratanya adalah $35.812,5 \quad \mathrm{CFU} / \mathrm{m}^{3}$. Kondisi sanitasi pada bus AC rata-rata adalah 67,25\% dan kondisi kebersihan pada bus non AC rata-rata adalah 51\%.yang. Keduanya dikategorikan cukup, karena berada antara 56\% - 75\%.

\section{Saran}

Perlu dilakukan penelitian lanjutan tentang jumlah mikroorganisme udara pada bus AC dan non AC Jurusan Purwokerto-Yogyakarta dengan jumlah sampel yang lebih banyak dan waktu pengambilan sampel yang beragam.

\section{DAFTAR PUSTAKA}

A.L Slamet Riyadi, 1982, Pencemaran Udara, Surabaya : Usaha Nasional.

Budiman Chandra, 2006, Pengantar Kesehatan Lingkungan, Jakarta : EGC

E.Jawetz, at al, 1986, Mikrobiologi Untuk Profesi Kesehatan, diterjemahkan oleh Gerard Bonang

Fajarsetiawan, 2010, Studi Sanitasi Kereta Api Kelas Bisnis Purwojaya Tahun 2010, Karya Tulis Ilmiah, Purwokerto : Kementerian Kesehatan RI Politeknik Kesehatan Semarang Jurusan Kesehatan Lingkungan Purwokerto.

Indan Entjang, 2003, Mikrobiologi \& Parasitologi, Bandung : Citra Aditya Bakti

Indonesia, Departemen Kesehatan R.I, 1994, Petunjuk Teknis Pengukuran Kualitas Udara dan Limbah Cair, Jakarta : Dirjen PPM \& PLP

Humas Departemen Perhubungan, 1993, Petunjuk Lalu Lintas dan Angkutan Jalan, Jakarta : BP Media Karya

Pusat Pendidikan Tenaga Kesehatan Departemen Kesehatan R.I, 1991, Buku Pedoman Mata Ajaran Mikrobiologi Lingkungan, Jakarta : Departemen Kesehatan R.I

Justisia Ayu Syailendra, 2005, Studi Jumlah Mikroorganisme Udara pada Bus AC dan Non AC Jurusan Purwokerto - Yogyakarta di Terminal Bus Purwokerto Tahun 2005, Karya 
Tulis Ilmiah, Purwokerto : Departemen Kesehatan RI Politeknik Kesehatan Semarang Jurusan Kesehatan Lingkungan Purwokerto.

Michael Pelczar, 1988, Dasar - DasarMikroiologi II, diterjemahkan oleh TejaImas, at al, Jakarta : Penerbit Universitas Indonesia

Mukono.blog.unair.ac.id. Diakses pada tanggal 1 Juli 2015 pukul 17.08 WIB.

Nurulita Budi Susanti, 2008, Studi Jumlah Mikroorganisme Udara Pada Bus AC dan Non AC Jurusan Purwokerto - Semarang Tahun 2008, Karya Tulis Ilmiah, Purwokerto : Departemen Kesehatan RI Politeknik Kesehatan Semarang Jurusan Kesehatan Lingkungan Purwokerto
Permenkes RI No/ 1405/Menkes/SK/XI/2002 tentang Persyaratan Kesehatan Lingkungan Kerja Perkantoran dan Industri

Srikandi Fardiaz, 1992, Polusi Air \& Udara, Yogyakarta : Kanisius

Suharsimi Arikunto, 1996, Prosedur Penelitian Suatu Pendekatan Praktek Edisi Revisi III, Yogyakarta ; Rineka Cipta

T. Hermaya, 1992, Ensiklopedi Kesehatan,Jakarta : PT. Cipta Adi Pustaka

Tri Cahyono, 2014, Pedoman Penulisan Proposal Penelitian dan Karya Tulis Ilmiah, Purwokerto : Kementerian Kesehatan R.I Politeknik Kesehatan Semarang Jurusan Kesehatan Lingkungan. 